\title{
Lipopolysaccharide’s Cytotoxicity on Human Umbilical Cord Mesenchymal Stem Cells
}

\author{
Mefina Kuntjoro ${ }^{1,2}\left(\mathbb{D}\right.$, Eric Priyo Prasetyo ${ }^{3}$, Febriastuti Cahyanis@ ${ }^{\circledR}$, Michael Josef Kridanto

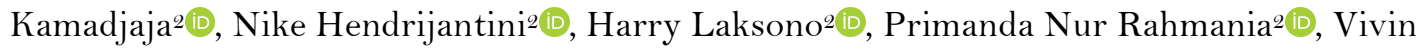

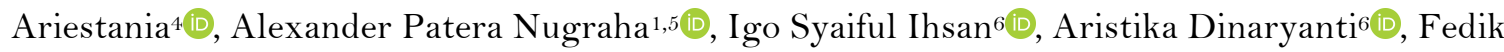 \\ Abdul Rantam 6,7 (1)
}

\begin{abstract}
'Doctoral Program, Faculty of Medicine, Universitas Airlangga, Surabaya, Indonesia.
${ }^{2}$ Department of Prosthodontics, Faculty of Dental Medicine, Universitas Airlangga, Surabaya, Indonesia.

${ }^{3}$ Department of Conservative Dentistry, Faculty of Dental Medicine, Universitas Airlangga, Surabaya, Indonesia.

${ }^{4}$ Doctoral Program, Faculty of Dental Medicine, Universitas Airlangga, Surabaya, Indonesia.

${ }^{5}$ Department of Orthodontics, Faculty of Dental Medicine, Universitas Airlangga, Surabaya, Indonesia.

${ }^{6}$ Stem Cell Research and Development Center, Universitas Airlangga, Surabaya, Indonesia.

${ }^{7}$ Laboratory of Virology and Immunology, Department of Microbiology, Faculty of Veterinary Medicine, Universitas Airlangga, Surabaya, Indonesia.
\end{abstract}

Author to whom correspondence should be addressed: Michael Josef Kridanto Kamadjaja, Department of Prosthodontics, Faculty of Dental Medicine, Universitas Airlangga, Jalan Mayjen Prof Dr Moestopo 47, Surabaya, Indonesia. Phone: +62 315030255. E-mail: Michael-j-k-k@fkg.unair.ac.id.

Academic Editor: Yuri Wanderley Cavalcanti

Received: 10 March 2020 / Accepted: 28 May 2020 / Published: 03 August 2020

How to cite this article: Kuntjoro M, Prasetyo EP, Cahyani F, Kamadjaja MJK, Hendrijantini N, Laksono H, et al. Lipopolysaccharide's cytotoxicity on human umbilical cord mesenchymal stem cells. Pesqui Bras Odontopediatria Clín Integr. 2020; 20:e0048. https://doi.org/10.1590/pboci.2020.153

\begin{abstract}
Objective: To show the cytotoxicity of Porphyromonas gingivalis lipopolysaccharide (LPS) on human umbilical cord mesenchymal stem cells (HUCMSCs) to better understand the characteristics for its application in regenerative procedures under periodontopathogen LPS influence. Material and Methods: Ultrapure Porphyromonas gingivalis LPS was used in this study. This research used a frozen stock HUCMSCs, previously confirmed by flow cytometry. The biological characteristics, such as cell morphology, proliferation, and protein expression, were screened. To check the cytotoxicity, HUCMSCs were cultured and divided into two groups, the control group and LPS group with various concentrations from 25 to $0.39 \mu \mathrm{g} / \mathrm{mL}$. MTT assay was done and the cells were observed and counted. The significance level was set at $5 \%$. Results: The percentage of living HUCMSCs on LPS group were not significantly different among concentrations ( $\mathrm{p}>0.05$ ) from 25 to $0.39 \mu \mathrm{g} / \mathrm{mL}$, even though there were slight mean decrease between groups, but they were not significant. The duration of 24 hours of exposure of LPS does not significantly lower HUCMSCs viability. Conclusion: LPS does not affect the viability of HUCMSCs. The lower the concentration of LPS, the higher the viability of HUCMSCs.
\end{abstract}

Keywords: Lipopolysaccharide; Viability; Umbilical cord; Mesenchymal stem cells; Cytotoxicity. 


\section{Introduction}

There are several mesenchymal stem cells (MSCs) sources available for clinical applications. Human umbilical cord mesenchymal stem cells (HUCMSCs) are MSCs found in the umbilical cords and may be a prospective candidate for use in tissue regeneration [1]. Compared to other sources of stem cells from adult tissues, HUCMSCs are more primitive, non-invasive in terms of collection, provide high proliferation potential, high differentiation potential, immune-privileged, immunosuppressive, and rich in stemness [Q].

One of the most common causes of tooth loss and endodontic treatment failures is a periodontal disease by a bacterial infection. Many of the infection is caused by gram-negative bacilli, such as Porphyromonas gingivalis $[3,4]$. These bacteria also cause periodontitis, peri-implantitis, and peri-implant mucositis infections $[5,6]$. Lipopolysaccharide (LPS) is an outer membrane unit of Gram-negative bacterial cell walls. It is also an endotoxin with a wide range of biological maneuvers. LPS can induce the release of several pro-inflammatory cytokines, which may lead to alveolar bone resorption and periodontal tissue destruction [7].

LPS does not indicate a single molecular type, but a molecule of diverse chain lengths with high and low molecular weights, which affect the biological activity [8]. Several studies have evaluated the increase of functional properties of MSCs by LPS exposure to defend against a harsh inflammatory environment [9,10]. However, few studies have used HUCMSCs on LPS exposure. Cell cultures are a useful technique to evaluate the biocompatibility of various materials [11,12]. In-vitro assessment of cell cultures are usually used to explore the mechanism and biological responses in certain conditions.

Even though results from in-vitro experiments cannot immediately be generalized to mimic clinical conditions, they are relevant as they reflect a model for screening of various material properties and risks [13]. By studying the viability of HUCMSCs under Porphyromonas gingivalis LPS influence, we can study further approach of regenerative procedures under this influence, such as in endodontics, periodontics, prosthodontics (implants) failures affected by periodontopathogen LPS. Previous studies about LPS on other stem cell sources, such as human periodontal ligament stem cells and stem cells from the apical papilla have used Porphyromonas gingivalis LPS but in limited concentrations, ranging from o to $5 \mu \mathrm{g} / \mathrm{mL}$ or 0 to $10 \mu \mathrm{g} / \mathrm{mL}$, with different and irregular intervals $[14,15]$.

Stem cells' viability and response may differ depending on the variation of contact from available LPS. An in-vitro study of LPS exposure on the apical papilla's stem cells did not affect its proliferation and mineralization. At a concentration of $5 \mathrm{mg} / \mathrm{mL}$, LPS increased bone sialoprotein gene expression [14].

There are other studies with non-periodontopathogen LPS from E. coli showed different results on how LPS effect stem cells in terms of reduced proliferation and growth factor secretion [16]. Therefore, as the first step of understanding HUCMSCs under periodontopathogen LPS condition, the purpose of this study was to investigate the cytotoxicity of various concentrations of Porphyromonas gingivalis LPS on the viability HUCMSCs, through MTT assay.

\section{Material and Methods}

Ethical Aspects

This study was permitted by the Health Research Ethical Clearance Commission, Universitas Airlangga Faculty of Dental Medicine, Surabaya, Indonesia (Clearance number 060/HRECC.FODM/II/2020).

Preparation of HUCMSCs

Previously isolated and characterized frozen stock HUCMSCs from the $4^{\text {th }}$ passage was obtained from Stem Cell Research and Development Center Universitas Airlangga (Surabaya, Indonesia). The HUCMSCs 
was previously confirmed by flow cytometric analysis using FACS Calibur (BD Biosciences, USA) and identified by specific antibodies for CD73, CD90, CD105, CD45, and CD34. There were positivity of CD73, CD90, CD105, negativity of CD45 and CD34. All antibodies were purchased from Becton-Dickinson (BD Biosciences, San Jose, CA USA).

The frozen HUCMSCs from $-80^{\circ} \mathrm{C}$ storage were thawed in a water bath with a temperature of $37^{\circ} \mathrm{C}$. Thawed HUCMSCs were moved to another tube containing $10 \mathrm{~mL}$ Minimum Essential Medium (MEM) alpha medium (Gibco, Paisley, UK) at $37^{\circ} \mathrm{C}$, then centrifuged for 5 minutes at $1600 \mathrm{rpm}$.

The supernatant was eliminated and the cell pellet was resuspended in culture medium in a $12 \mathrm{~mm}$ diameter plate. The resuspended cells were stored in an incubator for 6 hours at $37^{\circ} \mathrm{C}$. The evaluation was done using TMS inverted microscope (Nikon, Minato, Japan). The thawing of HUCMSCs was successful; the cells were expanded and ready for further treatment.

Lipopolysaccharide (LPS) Preparation for HUCMSCs

Ultrapure Porphyromonas gingivalis lipopolysaccharide (InvivoGen, San Diego, CA, USA) was used [17]. The LPS powder was diluted with MEM alpha medium into different concentrations. LPS dilution was done following the manufacturer's directions. LPS concentrations of $0.39,0.78,1.56,31.25,6.25,12.5$, and 25 $\mu \mathrm{g} / \mathrm{mL}$ were to be compared in this experiment. This concentration was observed because numerous studies are using different concentrations; therefore, we decided to divide and range it from 25 to $0 \mu \mathrm{g} / \mathrm{mL}$ gradually in a regular pattern. The experiments were performed in triplicate.

\section{Assessment of Viable HUCMSCs}

The viability of HUCMSCs on LPS was determined by methyl-thiazol-tetrazolium (MTT). The fifth passage HUCMSCs were seeded at a density of 5,000 cells per well in a 96-well culture plate (Iwaki, Asahi, Japan) and treated with LPS at concentrations ranging from 0.05-25 $\mu \mathrm{g} / \mathrm{mL}$ for 24 hours. Each well was given 200 microliter MEM alpha medium containing LPS according to the explored concentrations.

After incubation, MTT was added to each well and incubated for 3 hours, and then the process was stopped by the addition of 50 microliters of DMSO per well. Cell proliferation was examined by measuring optical density from a microplate reader (GloMax ${ }^{\circledR}$ Explorer, Promega Corporation, Fitchburg, WI, USA) at a wavelength of $595 \mathrm{~nm}$. Viable cells were seen under an inverted TMS microscope (Nikon Corp., Tokyo, Japan) with 100x magnification for cell distribution and morphology among the control and observed groups.

\section{Statistical Analysis}

The assessments were conducted and performed in triplicates with regard to previous studies [16,17] and sample size determination formula for controlled laboratory experiments. Data were provided as mean + standard deviation. Statistical analysis was done using SPSS20.0 for Windows (SPSS Inc., Chicago, Illinois, USA). All data were tested for normal distribution. One-way ANOVA test was used to compare 3 or more groups (among control and LPS groups of different concentrations). Post Hoc LSD (Least Significant Difference) test was used to investigate multiple comparisons of inter-group differences. The difference between groups was considered significant when $\mathrm{p}<0.05$.

\section{Results}

Viable cells seen under an inverted microscope with 100x magnification are available in Figure 1. There was no difference in cell distribution and morphology among the control and observed groups. The mean and standard deviation (SD) of control and lipopolysaccharide (LPS) groups are shown in Table 1. 


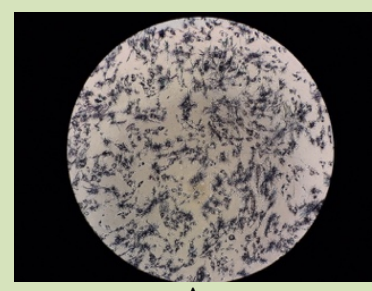

A

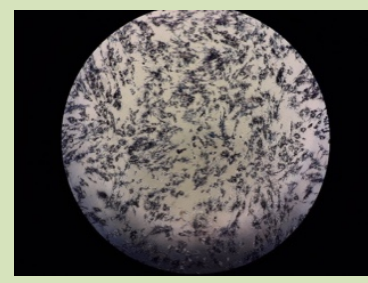

E

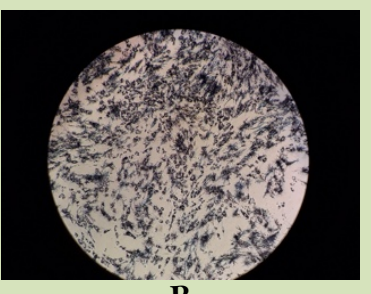

B

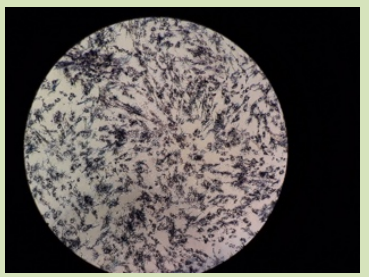

$\mathbf{F}$

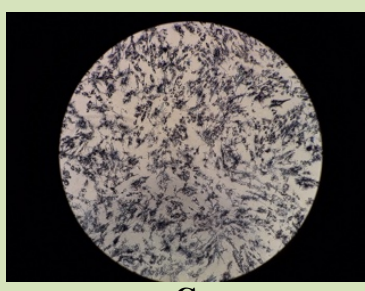

C

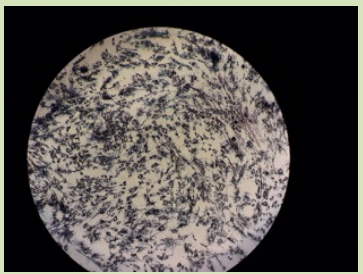

G

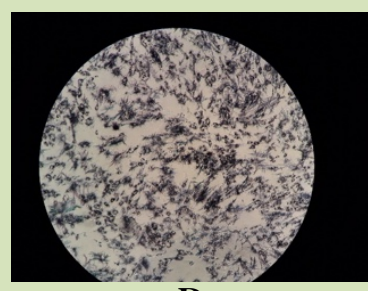

D

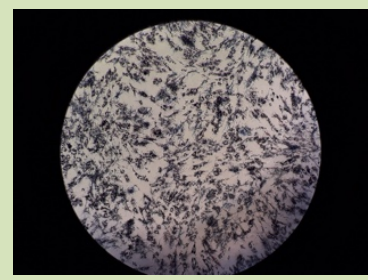

H

Figure 1. Viable cells seen under inverted microscope (100x magnification): control (A), LPS concentration of $25 \mu \mathrm{g} / \mathrm{mL}$ (B), $12.5 \mu \mathrm{g} / \mathrm{mL}$ (C), $6.26 \mu \mathrm{g} / \mathrm{mL}$ (D), $3.125 \mu \mathrm{g} / \mathrm{mL}$ (E), $1.56 \mu \mathrm{g} / \mathrm{mL}$ (F), $0.78 \mu \mathrm{g} / \mathrm{mL}(\mathrm{G})$, and $0.39 \mu \mathrm{g} / \mathrm{mL}(\mathrm{H})$.

Data in the result was normally distributed ( $>0.05)$, and homogeneity test yield homogeny data ( $p>0.05)$. MTT assay result of different lipopolysaccharide (LPS) concentrations showed no significant difference among $0.39,0.78,1.56,3.12,5.625,12.5$ and $25 \mu \mathrm{g} / \mathrm{mL}(\mathrm{p}>0.05)$.

Table 1. Mean and standard deviation of control and LPS groups.

\begin{tabular}{lc}
\hline \multicolumn{1}{c}{ Group } & $\begin{array}{c}\text { Cell Viability } \\
\text { Mean }(\mathrm{SD})\end{array}$ \\
\hline Control & $100 \pm 0.00$ \\
LPS 25 & $69.8193 \pm 4.02339$ \\
LPS 12.5 & $66.4653 \pm 4.22801$ \\
LPS 6.25 & $68.3773 \pm 3.00004$ \\
LPS 3.125 & $68.7017 \pm 2.88213$ \\
LPS 1.56 & $67.1853 \pm 3.32384$ \\
LPS 0.78 & $66.9630 \pm 2.51683$ \\
LPS 0.39 & $67.1697 \pm 2.91831$ \\
\hline
\end{tabular}

\section{Discussion}

There is a higher interest in searching the prospects of human umbilical cord mesenchymal stem cells (HUCMSC) because this stem cell can be isolated and expanded easily in large quantities, and non-invasive compared to commonly used bone marrow mesenchymal stem cells [18]. There are studies about other MSC sources, but little information was available regarding HUCMSC and its potential use in pulpal and periapical regeneration.

Pulpal and periapical regenerative researches using MSCs are hoped to be an alternative to treat various pathological conditions, such as chronic inflammation involving lipopolysaccharide (LPS). However, it stays unclear how LPS could influence MSC to resolve inflammation. Some research on LPS preconditioning of MSC has been an increasing approach for tissue injury and inflammatory disease therapy [19].

HUCMSCs were cultured in minimum essential medium alpha (MEM-A) containing ultrapure Porphyromonas gingivalis LPS in various concentrations from 0 to $25 \mu \mathrm{g} / \mathrm{mL}$. We chose this range of concentrations because previous studies use different and limited concentrations of LPS in their methods; therefore, we expand the concentrations from o to $25 \mu \mathrm{g} / \mathrm{mL}$. We use LPS from Porphyromonas gingivalis 
because it is among the most common species in primary root canal infection [14]. The cells were incubated under normal culture conditions at $37^{\circ} \mathrm{C}$ and $5 \% \mathrm{CO}_{2}$.

We used MTT assay to determine cell viability and determine cytotoxicity under periodontopathogen LPS influence. MTT assay is mostly chosen to determine cytotoxicity and proven to be more accurate and practical. The MTT assay principle is to break the tetrazolium ring (3-(4,5-dimethylthiazole-2-yl)-2,5 diphenyl tetrazolium bromide) to produce insoluble blue-purple formazan crystals. The living cells can be measured using optical density spectrophotometry. The lower the optical density means the lower living cells to metabolize MTT.

In this study, there were no differences in HUCMSCs viability among various concentrations of LPS, meaning LPS is not toxic to HUCMSCs within these concentrations. This finding might assume that LPS could enhance paracrine protective effects and regenerative healing of HUCMSCs. This condition might be related with the finding of other studies that LPS influence mesenchymal stem cells to create a suitable milieu to promote tissue repair and reduce inflammation through a paracrine mechanism and exosomes [20].

Exosomes are small vesicles carrying bioactive molecules, such as microRNAs (miRNAs), messenger RNAs (mRNAs) and protein. These bioactive molecules can be passed between cells to influence cellular activities and metabolism in recipient cells [2 1,22]. Exosomes contain many genetic molecules that act as cellto-cell communication channels to alter genetic expression in recipient cells [19].

Previous study on human periodontal ligament cells showed that both pretreatment and nonpretreatment of LPS have higher production of pro-inflammatory mediators [23]. LPS plays a crucial role in the pathogenesis of apical lesions by releasing pro-inflammatory cytokines. We found that LPS has no toxicity on HUCMSCs on the given concentrations. This research is in line with previous study on stem cells from the apical papilla that LPS concentration of o to $5 \mu \mathrm{g} / \mathrm{mL}$ did not affect cell viability [14]. This might be caused by the fact that LPS have induced HUCMSCs to hold a cytoprotection potential, but further study needs to be done. The survival of HUCMSCs will ensure the paracrine effect for tissue regeneration and regulation of antiinflammation through an immunomodulatory effect on immune cells responses [24,25].

\section{Conclusion}

These results show LPS does not significantly affect the viability of HUCMSCs depending on the concentration used. In conclusion, this study provides evidence that LPS is not toxic to HUCMSCs within tested concentrations. However, this study is limited to Porphyromonas gingivalis LPS within a range of 0 to 25 $\mu \mathrm{g} / \mathrm{mL}$, to find out more, further studies need to be conducted with higher concentrations. Further in-vitro and in-vivo studies will also be required to reveal more novel mechanisms of Porphyromonas gingivalis LPS on HUCMSCs for regenerative purposes in endodontics, periodontics, prosthodontics, pediatric dentistry, oral and maxillofacial surgery.

\section{Authors' Contributions}

\begin{tabular}{|c|c|c|}
\hline MK & (iD) $0000-0002-3869-754 \mathrm{X}$ & $\begin{array}{l}\text { Conceptualization, Methodology, Formal Analysis, Investigation, Resources, Writing - } \\
\text { Original Draft, Project Administration. }\end{array}$ \\
\hline EPP & (iD) $0000-0001-9962-235 \mathrm{X}$ & $\begin{array}{l}\text { Conceptualization, Methodology, Formal Analysis, Resources, Writing - Original Draft, } \\
\text { Writing - Review and Editing and Funding Acquisition. }\end{array}$ \\
\hline $\mathrm{FC}$ & (iD) $0000-0001-6363-8093$ & Conceptualization, Methodology, Formal Analysis and Funding Acquisition. \\
\hline MJKK & (iD) $0000-0003-3226-7781$ & Conceptualization, Investigation, Resources, Supervision and Funding Acquisition. \\
\hline NH & (iD) $0000-0002-9261-3626$ & Methodology, Investigation, Resources, Supervision and Project administration. \\
\hline HL & (iD) $0000-0002-8708-4731$ & Writing - Original Draft, Writing - Review and Editing and Project Administration. \\
\hline
\end{tabular}




\begin{tabular}{|c|c|c|}
\hline PNR & (iD) $0000-0001-8390-9284$ & Methodology, Investigation, Resources, Supervision and Project administration. \\
\hline VA & (iD) $0000-0002-3002-0825$ & Methodology, Investigation, Writing - Original Draft and Writing - Review and Editing. \\
\hline APN & (iD) $0000-0001-7427-7561$ & Methodology, Investigation, Writing - Original Draft and Writing - Review and Editing. \\
\hline ISI & (iD) 0000-0001-9038-0358 & Methodology, Software, Validation, Formal Analysis, Investigation and Data Curation. \\
\hline $\mathrm{AD}$ & (iD) $0000-0001-7114-5846$ & Methodology, Software, Validation, Formal Analysis, Investigation and Data Curation. \\
\hline FAR & (iD) $0000-0001-8182-1465$ & Methodology, Investigation, Resources, Supervision and Project administration. \\
\hline
\end{tabular}

\section{Financial Support}

Lembaga Pengelola Dana Pendidikan Kementerian Keuangan Republik Indonesia and Faculty of Dental Medicine Universitas Airlangga, Surabaya, Indonesia (Grant Number 2143/2019).

\section{Conflict of Interest}

The authors declare no conflicts of interest.

\section{Acknowledgement}

The authors thank the Publication Center, Faculty of Dental Medicine for technical supports.

\section{References}

[1] Meguid EA, Ke Y, Ji J, El-Hashash AHK. Stem cells applications in bone and tooth repair and regeneration: New insights, tools, and hopes. J Cell Physiol 2018; 233(3):1825-35. https://doi.org/10.1002/jcp.25940

[2] Li T, Xia M, Gao Y, Chen Y, Xu Y. Human umbilical cord mesenchymal stem cells: an overview of their potential in cell-based therapy. Expert Opin Biol Ther 2015; 15(9):1293-1306. https://doi.org/10.1517/14712598.2015.1051528

[3] Paster BJ, Olsen I, Aas JA, Dewhirst FE. The breadth of bacterial diversity in the human periodontal pocket and other oral sites. Periodontol 2000 2006; 42:80-7. https://doi.org/10.1111/j.1600-0757.2006.00174.x

[4] Philstrom BL, Michalowicz BS, Johnson NW. Periodontal diseases. Lancet 2005; 366(9499):1809-20. https://doi.org/10.1016/So140-6736(05)67728-8

[5] Belibasakis GN. Microbiological and immuno-pathological aspects of peri-implant diseases. Arch Oral Biol 2014; 59(1):66-72. https://doi.org/10.1016/j.archoralbio.2013.09.013

[6] Charalampakis G, Leonhardt A, Rabe P, Dahlén G. Clinical and microbiological characteristics of peri-implantitis cases: a retrospective multicenter study. Clin Oral Impl Res 2012; 23(9):1045-54.

https://doi.org/10.1111/j.1600-0501.2011.02258.x

[7] Graves DT, Oates T, Garlet GP. Review of osteoimmunology and the host response in endodontic and periodontal lesions. J Oral Microbiol 2011; 3(1):5304. https://doi.org/10.3402/jom.v3io.5304

[8] Hong CY, Lin SK, Kok SH, Cheng SJ, Lee MS, Wang TM et al. The role of lipopolysaccharide in infectious bone resorption of periapical lesion. J Oral Pathol Med 2004; 33(3):162-9. https://doi.org/10.1111/j.0904-25 12.2004.00045.x

[9] Yao Y, Zhang F, Wang L, Zhang G, Wang Z, Chen J, et al. Lipopolysaccharide preconditioning enhances the efficacy of mesenchymal stem cells transplantation in a rat model of acute myocardial infarction. J Biomed Sci 2009; 16(1):74. https://doi.org/10.1186/1423-0127-16-74

[10] Crisostomo PR, Wang Y, Markel TA, Wang M, Lahm T, Meldrum DR. Human mesenchymal stem cells stimulated by TNF-alpha, LPS, or hypoxia produce growth factors by an NF kappa B- but not JNK-dependent mechanism. Am J Physiol Cell Physiol 2008; 294(3):C675-82. https://doi.org/10.1152/ajpcell.00437.2007

[11] Peters OA. Research that matters - biocompatibility and cytotoxicity screening. Int Endod J 2013; 46(3):195-7. https://doi.org/10.1111/iej.12047

[12] Collado-Gonzales M, García-Bernal D, Oñate-Sánchez RE, Ortolani-Seltenerich PS, Álvarez-Muro T, Lozano A, et al. Cytotoxicity and bioactivity of various pulpotomy materials on stem cells from human exfoliated primary teeth. Int Endod J 2017; 50(Suppl 2):e19-e30. https://doi.org/10.1111/iej.12751

[13] Pires CW, Botton G, Cadoná FC, Machado AK, Azzolin VF, Cruz IBM, et al. Induction of cytotoxicity, oxidative stress and genotoxicity by root filling pastes used in primary teeth. Int Endod J 2016; 49(8):737-45. https://doi.org/10.1111/iej.12502

[14] Lertchirakarn V, Aguilar P. Effects of lipopolysaccharide on the proliferation and osteogenic differentiation of stem cells from the apical papilla. J Endod 2017; 43(11):1835-40. https://doi.org/10.1016/j.joen.2017.06.024

[15] Kato H, Taguchi Y, Tominaga K, Umeda M, Tanaka A. Porphyromonas gingivalis LPS inhibits osteoblastic differentiation and promotes pro-inflammatory cytokine production in human periodontal cytokine production in 
human periodontal ligament stem cells. Arch Oral Biol 201; 59(2):167-75. https://doi.org/10.1016/j.archoralbio.2013.11.008

[16] Keong JY, Low LW, Chong JM, Ong YY, Pulikkotil SJ, Singh G, et al. Effect of lipopolysaccharide on cell proliferation and vascular endothelial growth factor secretion of periodontal ligament stem cells. Saudi Dent J 2020; 32(3):148-54. https://doi.org/10.1016/j.sdentj.2019.08.001

[17] Memedovski Z, Czerwonka E, Han J, Mayer J, Luce M, Klemm LC, et al. Classical and alternative activation of rat microglia treated with ultrapure Porphyromonas gingivalis lipopolysaccharide in vitro. Toxins 2020; 12(5):333. https://doi.org/10.3390/toxins 12050333

[18] Hendrijantini N. Comparative in vitro study of the cytotoxicity of gelatin and alginate to human umbilical cord mesenchymal stem cells. Dent J 2019; 52(1):36-40. https://doi.org/10.20473/j.djmkg.v52.i1.p36-40

[19] Ti D, Hao H, Tong C, Liu J, Dong L, Zheng J, et al. LPS-preconditioned mesenchymal stromal cells modify macrophage polarization for resolution of chronic inflammation via exosome-shuttled let-7b. J Transl Med 2015; 13:308. https://doi.org/10.1186/s12967-015-0642-6

[20] Blazquez R, Sanchez-Margallo FM, de la Rosa O, Dalemans W, Alvarez V, Tarazona R, et al. Immunomodulatory potential of human adipose mesenchymal stem cells derived exosomes on in vitro stimulated T Cells. Front Immunol 2014; 5:556. https://doi.org/10.3389/fimmu.2014.00556

[21] Corrado C, Raimondo S, Chiesi A, Ciccia F, De Leo G, Alessandro R. Exosomes as intercellular signaling organelles involved in health and disease: basic science and clinical applications. Int J Mol Sci 2013; 14(3):5338-66. https://doi.org/10.3390/ijms 14035338

[22] Yu B, Zhang X, Li X. Exosomes derived from mesenchymal stem cells. Int J Mol Sci 2014; 15(3):4142-57. https://doi.org/10.3390/ijms 15034142

[23] Blufstein A, Behm C, Nguyen PQ, Rausch-Fan X, Andrukhov O. Human periodontal ligament cells exhibit no endotoxin tolerance upon stimulation with Porphyromonas gingivalis lipopolysaccharide. J Periodont Res 2018; 53(4):589-97. https://doi.org/10.1111/jre.12549

[24] Tipnis S, Viswanathan C, Majumdar AS. Immunosuppresive properties of human umbilical cord-derived mesenchymal stem cells: role of B7-H1 and IDO. Immunol Cell Biol 2010; 88(8):795-806. https://doi.org/10.1038/icb.2010.47

[25] Zhou C, Yang B, Tian Y, Jiao H, Zheng W, Wang J, et al. Immunomodulatory effect of human umbilical cord Wharton's jelly-derived mesenchymal stem cells on lymphocytes. Cell Immunol 2011; 272:33-8. https://doi.org/10.1016/j.cellimm.2011.09.010 